\title{
Chapter 2 \\ Market Wage, Child Care \\ and the Employment of Married Women
}

\begin{abstract}
This study analyzes the market wage, reservation wage, and unearned income on the probability of work participation of married women by using the longitudinal data of China Health and Nutrition Survey from 1989 to 2015 and a random effects probit model to address the heterogeneity problem. It is found the market wage positively affects the probability of work participation of married women; the reservation wage negatively affects the probability of work participation of married women; but the effect of unearned income is not statistically significant, which contrasts with most studies of developed countries. These effects differ by age and hukou (urban and rural) groups.
\end{abstract}

Keywords Wage $\cdot$ Child care $\cdot$ Employment $\cdot$ Married women $\cdot$ China

\subsection{Introduction}

Female labor force participation changes with economic development, which may influence not only individual or household consumption behavior but also the population structure and future economic growth (Goldin 1990). In developed countries, the empirical study of female employment, especially the employment of married women, is one of the most important research issues (Smith 1980; Killingsworth and Heckman 1986; Goldin 1990; Blundell and MaCurdy 1999). It has been pointed out that economic factors such as the market wage, the reservation wage (e.g., child care), and unearned income greatly influence the employment of married women (Hofferth 1984; Waite et al. 1985; O'Connell and Bloom 1987; Wenk and Garrett 1992; Del Boca et al. 2004; Buckles 2008; Miller 2011), but few empirical studies focus on China. ${ }^{3}$ This study mitigates this neglect.

Regarding female labor force participation in China, in the period of the planned economy (1949-1977), the Chinese government enforced a set of policies to promote gender equality at work and in society; as a result, the employment of women was promoted, and the gender gap in the labor market was not noticeable (Gustaffson and Li 2000; Pan 2002; Ma 2011). However, since the 1978, as China reformed its economic system from a planned economy to a market-oriented economy, the employment status of women has changed greatly. For example, in state-owned 
enterprises (SOEs), the proportion of laid-off workers was higher for females than for males when SOE reform was promoted by the Chinese government, ${ }^{1}$ and the gender wage gap increased during the market-oriented economy reform period (Ma 2009a, 2018a, b; Iwasaki and Ma 2020). In addition, it was found that the female labor force participation rate decreased in the current period. China's population is aging. In additions, in China, population aging is rapidly progressing in recent years. Based on the data of National Bureau of Statistics (2019), the percentage of population aged 65 and over to total population (the aging population ratio) increased from $4.2 \%$ in 1982 to $7.0 \%$ in 2000 , and $10.5 \%$ in 2015 ; It is predicted that the Chinese aging population ratio will reach $14 \%$ in 2026 , which means that the population aging will progress quickly for China than the developed countries such as Japan in the future. Therefore, increasing the female labor force participation rate (FLFPR) has become an important issue for the Chinese government. Moreover, the family and population policies, which are related to female employment, have changed in the 2000s. As it is well known, the Chinese government enforced a one-child policy ${ }^{2}$ since 1979, and the total fertility rate (TFR) decreased greatly after the policy's implementation. To address the imbalance of the demographic structure, the Chinese government abolished the one-child policy and implemented a set of population policies such as the selective two-child policy in the 2000s and the universal two-child policy in 2016. ${ }^{3}$ It can be assumed that these population policy changes may influence women, particularly married women's employment. Thus, empirical study of the determinants of the employment of married women in China has become an important issue. However, although some research has focused on the issue, studies on the impact of the market wage, the reservation wage (e.g., child care), and unearned income (e.g., husband's income)—which has been investigated for developed countries—are scarce for China. This study can remedy this neglect.

Using long-term longitudinal survey data (CHNS: China Health and Nutrition Survey from 1989 to 2015), this study investigates economic factors-including the market wage, the reservation wage, and unearned income-on the probability of participation in work of Chinese married women. A random effects (RE) probit regression model is used to address the heterogeneity problem, which was not considered in most previous studies.

The remainder of the chapter is structured as follows: Sect. 2.2 reviews the related theories and summarizes the results of previous empirical studies on the effects of the market wage, the reservation wage, and unearned income on the employment of married women. Section 2.3 presents the empirical method, including the models, data, and variable setting. Section 2.4 reports the descriptive statistical results. Section 2.5 presents and discusses results of the econometric analysis. The final section summarizes the conclusions and policy implications. 


\subsection{Literature Review}

\subsubsection{Economic Theories on the Labor Supply}

From the labor supply perspective, according to the general equilibrium model (individual utility maximum model), an individual's choice to participate in work is determined by economic factors - the market wage, the reservation wage (e.g., child care), and unearned income (e.g., husband's income) as follows.

First, when the market wage exceeds the reservation wage, an individual is likely to work.

Second, when unearned income rises, the labor supply may decrease if leisure time is a superior good.

Third, when the market wage rises, the labor supply may increase due to the substitution effect, while the labor supply may decrease due to the income effect if leisure is a superior good. Because the influence of changes in the market wage on the labor supply depends on two effects-the substitution effect and the income effect - the net effect of the market wage on the labor supply is not clear.

In addition, it should be considered that some noneconomic factors such as gender role consciousness and unobserved individual heterogeneity may also affect the choice to work.

To sum up, from the economics theory of labor supply perspective and individual heterogeneity, which determine each individual's preference for work or leisure, the influences of the market wage, the reservation wage, and unearned income are not clear. An empirical study should be conducted to estimate the effects of these factors.

\subsubsection{Empirical Studies on the Impact of the Market Wage, Child Care, and Unearned Income on the Employment of Married Women}

In this section, we mainly summarize the results of the effects of the market wage, the reservation wage (e.g., child care), and unearned income (e.g., husband's income) on the labor supply of married women. ${ }^{4}$

First, for the effects of the market wage, the results of empirical studies are mixed. For example, Layard et al. (1980), Franz and Kawasaki (1981), and Zabalza (1983) found that the market wage positively influences the employment of married women, while Nakamura and Nakamura (1981) reported that the market wage negatively affects the employment of married women aged 35-39. Dooley (1982) confirmed the negative effect for black married women aged 35-39 and 40-44, and Blundell and Walker (1982) reported that when controlling for the husband's work hours, the market wage negatively affects the employment of wives with two children. For China, Ma (2009a) found that the market wage positively affected the employment 
of married women in 2002, while the effect of the market wage was not significant in 1995.

Second, regarding the impact of the reservation wage (particularly child care) on the employment of married women, for developed countries, Hofferth (1984), Waite et al. (1985), O'Connell and Bloom (1987), Wenk and Garrett (1992), Del Boca et al. (2004), Buckles (2008), and Miller (2011) reported that the number of children negatively affects the employment of mothers. The results for China are mixed. For example, Jia et al. (2013) and Yu and Xie (2014) found that the women' employment changed after childbearing. Zhang (2011) and Yang and Bai (2017) reported that the number of children negatively affects the women' participation in work. However, Ma (2009a) found that the influence of the youngest child's age is not statistically significant.

In addition, the labor supply also affects the choice of employment status (choosing to become a regular worker or an irregular worker). For the association of child care and irregular work, in studies of developed countries, Bardasi and Gornick (2000) used international data from five developed countries (Canada, Germany, Italy, the UK, and the USA) and found that the mothers are more likely than childless women to become part-time workers. Drobnic et al. (1996) found that, in Germany, the probability of becoming part-time workers is higher for mothers. Shikata and Ma (2006) and Ma (2008, 2009b) found that, in Japan, women with a younger child or with more children are more likely to become irregular workers. However, empirical studies about child care and irregular work are scarce for China. ${ }^{5}$

Third, for the effects of unearned income, the results of empirical studies are mixed. Heckman (1976, 1980), Cogan (1980a, b), Schulz (1980), Hanoch (1980), Zabalza (1983), and Franz and Kawasaki (1981) found that when the husband's income rises, the labor supply of married women increases; the elasticities of the husband's income to the wife's labor supply are positive values from 0.03 to 15.35. However, Nakamura, Nakamura, and Cullen (1980) and Nakamura and Nakamura (1981) reported that the wife's labor supply decreases as her husband's income rises; the elasticities of the husband's income to the wife's labor supply are negative values from -0.12 to -1.06 . For China, Ma (2009a) used Chinese Household Income Project survey (CHIPs 1995 and CHIPs 2002) data and found that although unearned income (household income excluding the respondent's income) negatively affected the employment of urban married women in both 1995 and 2002, the effect of unearned income is not significant.

As compared with previous studies, the main contributions of this study can be summarized as follows. First, although empirical studies for both developed countries and China found that the market wage, child care, and unearned income influence the employment of married women, the results are mixed. This can be explained by the survey data and methodology. Concretely, in most of these previous studies, crosssectional survey data were used. Because of gender role consciousness or unobservable personality differences in individuals, the heterogeneity problem may remain in these results. This study uses longitudinal survey data and a random effects model to address the heterogeneity problem. Second, China has experienced an economic transition from a planned economy to a market-oriented economy; therefore, the 
mechanism of the labor supply of married women may differ from those in developed countries. However, empirical studies about the influences of the market wage, child care, and the husband's income for China are scarce. Although Ma (2009a, b) analyzed the issue, the analyzed periods are 1995 and 2002, and new analysis using the latest survey data is needed. By using CHNS from 1989 to 2015, this study can provide new evidence for the issue.

\subsection{Methodology and Data}

\subsubsection{Model}

First, the market wage of married women is an imputed wage based on the wage function. To address the sample selection bias, the Heckman two-step model (Heckman 1979 ) is used, which is expressed by Eqs. (1.1) and (1.2):

$$
\begin{gathered}
\operatorname{Pr}\left(Y_{i}^{*}>0\right)=\operatorname{Pr}\left(\alpha+\beta_{H} H_{i}+\mu_{i}>0\right) \\
\ln \text { Wage }_{i}=b+\gamma_{1} X_{i}^{\prime}+\gamma_{2} \lambda_{i}+\epsilon_{i}
\end{gathered}
$$

In Eqs. (1.1) and (1.2), $i$ indicates the individual, $\operatorname{Pr}\left(Y_{i}^{*}>0\right)$ is the probability of participation in work, and $\ln W a g e$ is a logarithmic value of the hourly wage. $H, X$ expresses the variables, $\beta, \gamma$ is the coefficient of each variable, $a, b$ is a constant item, and $\mu, \in$ is an error item. The adjusted item $(\lambda)$ is calculated based on the density function and the distribution function of the probit regression model $(\lambda=\phi(.) / \Phi()$.$) .$

Second, the probability of participating in work can be estimated by using the probit regression model:

$$
\operatorname{Pr}\left(Y_{i}^{*}>0\right)=\operatorname{Pr}\left(c+\beta_{1} \bar{W}_{i}+\beta_{2} R W_{i}+\beta_{3} \mathrm{Hin}_{i}+\beta_{4} X_{i}+\varepsilon_{i}>0\right) .
$$

In Eq. (2.1), $i$ indicates the individual, $c$ is constant, $\bar{W}$ is the imputed market wage of married women, $R W$ is the reservation wage (here, the number of children and the age of the youngest child), Hin is unearned income (here, the husband's income), $X$ is another variable, $\beta$ are the coefficients of variables, and $\varepsilon$ is the error term.

If $\varepsilon$ includes an individual-specific, time-invariant factor $\left(u_{i}\right)$, heterogeneity problems may occur when it is not considered. To address this problem, a random effects (RE) probit regression model is used. The RE probit regression model is expressed by Eq. (2.2):

$$
\operatorname{Pr}\left(Y_{i t}^{*}>0\right)=\operatorname{Pr}\left(c+\beta_{1} \bar{W}_{i t}+\beta_{2} R W_{i t}+\beta_{3} H_{i n}+\beta_{4} X_{i t}+u_{i}+v_{i t}>0\right) .
$$


In Eq. (2.2), $i$ indicates the individual; $t$ represents the year; $u_{i}$ is an individualspecific, time-invariant factor; and $v_{i t}$ is the real error term.

To estimate the probability of employment status, including three types-(A) nonwork, (B) irregular work, and (C) regular work-a multinomial probit regression model is used, which is expressed by Eqs. (2.3.1)-(2.3.3):

$$
\begin{gathered}
\operatorname{Pr}\left(Y_{A i}^{*}>0\right)=\operatorname{Pr}\left(a+\beta_{A}^{\prime} X_{A i}^{\prime}+e_{A i}>0, c+\beta_{c}^{\prime} X_{c i}^{\prime}+e_{c i}<a+\beta_{A}^{\prime} X_{A i}^{\prime}+e_{A i}\right), \\
\underset{B}{\operatorname{Pr}}\left(Y_{B i}^{*}>0\right)=\operatorname{Pr}\left(b+\beta_{B}^{\prime} X_{B i}^{\prime}+e_{B i}>0, c+\beta_{c}^{\prime} X_{c i}^{\prime}+e_{c i}<0, a+\beta_{A}^{\prime} X_{A i}^{\prime}+e_{A i}<0\right), \\
\underset{C}{\operatorname{Pr}}\left(Y_{c i}^{*}>0\right)=\operatorname{Pr}\left(c+\beta_{c}^{\prime} X_{c i}^{\prime}+e_{c i}>0, c+\beta_{c}^{\prime} X_{c i}^{\prime}+e_{c i}>a+\beta_{A}^{\prime} X_{A i}^{\prime}+e_{A i}\right) .
\end{gathered}
$$

\subsubsection{Data and Variable Setting}

Data from the China Health and Nutrition Survey (CHNS) from 1989 to 2015 are used in this study. CHNS is a nationwide longitudinal survey data conducted by the Carolina Population Center of the University of North Carolina and the National Institute for Nutrition and Health (NINH, formerly the National Institute of Nutrition and Food Safety) at the Chinese Center for Disease Control and Prevention (CCDC). The survey took place over a 7-day period using a multistage, random cluster process to draw samples from 15 provinces and municipal cities (Liaoning, Heilongjiang, Jiangsu, Shandong, Henan, Hubei, Hunan, Guangxi, Guizhou, Beijing, Shanghai, Chongqing, Shaanxi, Yunnan, Zhejiang) that vary substantially in geography, economic development, and government resources. Three provinces were added in CHNS 2011, and another three provinces joined in 2015. In 1989 of initial survey year, the CHNS surveyed 3,795 households and 15,907 individuals. This study uses data from 10 waves, including the most recently updated data from 2015 . The CHNS provides extensive information about fertility and pregnancy history as well as basic social demographic and employment information that facilitate the empirical analysis in this study.

This study investigates the determinants of the employment of married women. The marriage of very young females is regulated by law, and the mandatory retirement age of female workers in the public sector (e.g., government organizations, SOEs) ranges from 45 to 55. Therefore, this study is limited to samples of married women aged 20-44 years, which includes the period of child bearing and child care.

The main dependent variable is a binary probability variable equal to 1 when a woman is working and equal to 0 when she is not working. 
The main independent variables are the market wage, the reservation wage, and unearned income. (1) The market wage is an imputed value calculated based on the wage function by using the Heckman two-step model. The dependent variable of the wage function is the logarithmic value of the hourly wage, which is adjusted by the 1989 CPI (consumer price index). The variables in the first step estimation (the function of probability of work participation) include the wife's years of schooling, age and age squared, minority ethnicity, husband's income and squared, number of children, the age of the youngest child, urban/rural hukou, region, and survey year dummy variables; the variables in the second-step estimation (the wage function) include the wife's years of schooling, years of work experience and squared, minority ethnicity, urban/rural hukou, region, and survey year dummy variables. The results of the wage function are shown in Appendix Table 2.6. The coefficient of the adjusted item $(\lambda)$ is a negative value and statistically significant at a $1 \%$ level, indicating that a sample selection bias problem remains in the results based on the OLS. The coefficients of the wage function are used to calculate the imputed market wage. (2) Three dummy variables of the number of children — one, two, three, and more-and five kinds of dummy variables of the age of the youngest child $-0-1,2-3,4-5,6-14$, or 15 years and older-are used as indices of the reservation wage. It is assumed that the labor supply of married women may decrease for the group with younger children and with more children. (3) The logarithmic value of the husband's income is used as the index of the unearned income of married women, which is adjusted by the $1989 \mathrm{CPI}$.

The other covariates are used to control other influences on the women' employment. (1) The culture and willingness to work may differ for the various ethnic groups; therefore, the minority ethnicity dummy (Han ethnicity $=0$; minority ethnicity $=1$ ) is used. (2) In China, there is considerable disparity of culture, lifestyle and social policies between rural and urban areas as related to family size, gender role consciousness, as well as formal and informal child care support and the public provision of child care (Zhang 2011). Therefore, the urban dummy variable (urban areas $=1$; rural areas $=0$ ) is constructed to control these disparities. (3) The level of economic development and the macroeconomic environment differ by region and survey year. Four region dummy variables (Eastern Region, Central Region, Western Region, and Northeast Region) and three period dummy variables (periods from 1989 to 1997 , 2000 to 2006, and 2009 to 2015) are used.

Table 2.1 presents the descriptive statistics of variables by working and nonworking married women. We employed the $t$-test to investigate the differences between these two groups. In general, the total employment rate (percentage of working individuals to the total samples in each group) is $83.1 \%$; the proportions of nonworkers, irregular workers, and regular workers are, respectively, 16.9\%, 49.6\% and $33.4 \%$ for married women aged $20-44$. It is observed that the individual characteristics of these two groups differ significantly. For example, working married women have fewer years of schooling and are less likely to have children aged 03 than non-working group. Economic factors of these two groups also differ. For example, the imputed market wage and husband's income are lower for working 
Table 2.1 Descriptive statistics of variables

\begin{tabular}{l|l|l|l|l|l}
\hline & Total (a) & Work (b) & Non-work (c) & D (b)-(c) & t-test \\
\hline LP & 0.831 & 1 & 0 & & \\
\hline
\end{tabular}

Employment status

\begin{tabular}{|c|c|c|c|c|c|}
\hline Non-work & 0.169 & 0 & 1 & & \\
\hline Irregular & 0.496 & 0.597 & 0 & & \\
\hline Regular & 0.334 & 0.403 & 0 & & \\
\hline Imputed wage & 8.713 & 8.678 & 9.153 & $-0.475 * * *$ & $p<0.001$ \\
\hline Wife' years of schooling & 7.715 & 7.575 & 8.384 & $-0.809 * * *$ & $p<0.001$ \\
\hline Husband' years of schooling & 9.051 & 9.018 & 9.193 & $-0.175 * * *$ & 0.008 \\
\hline \multicolumn{6}{|l|}{ Number of children } \\
\hline One & 0.496 & 0.464 & 0.521 & $-0.057 * * *$ & $p<0.001$ \\
\hline Two & 0.352 & 0.356 & 0.384 & $-0.028 * * *$ & $p<0.001$ \\
\hline Three and more & 0.153 & 0.180 & 0.095 & $0.085 * * *$ & $p<0.001$ \\
\hline \multicolumn{6}{|l|}{ Age of youngest child } \\
\hline Age $0-1$ & 0.115 & 0.112 & 0.166 & $-0.054 * * *$ & $p<0.001$ \\
\hline Age $2-3$ & 0.121 & 0.122 & 0.125 & $-0.003 * * *$ & 0.603 \\
\hline Age $4-5$ & 0.118 & 0.122 & 0.092 & $0.030 * * *$ & $p<0.001$ \\
\hline Age 6-14 & 0.454 & 0.465 & 0.385 & $0.080 * * *$ & $p<0.001$ \\
\hline Age 15 and over & 0.192 & 0.178 & 0.233 & $-0.055^{* * * *}$ & $p<0.001$ \\
\hline Unearned income & 9.797 & 9.805 & 9.835 & $-0.030 * * *$ & $p<0.001$ \\
\hline Minority ethnicity & 0.130 & 0.122 & 0.120 & $0.002 * * *$ & 0.676 \\
\hline Urban & 0.287 & 0.297 & 0.152 & $0.145 * * *$ & $p<0.001$ \\
\hline \multicolumn{6}{|l|}{ Region } \\
\hline East & 0.232 & 0.251 & 0.187 & $0.064 * * *$ & $p<0.001$ \\
\hline Central & 0.355 & 0.339 & 0.398 & $-0.059 * * *$ & $p<0.001$ \\
\hline West & 0.254 & 0.251 & 0.207 & $0.044 * * *$ & $p<0.001$ \\
\hline Northeast & 0.159 & 0.160 & 0.208 & $-0.048 * * *$ & $p<0.001$ \\
\hline \multicolumn{6}{|l|}{ Period } \\
\hline у 1989-1997 & 0.413 & 0.518 & 0.161 & $0.357 * * *$ & $p<0.001$ \\
\hline у 2000-2006 & 0.297 & 0.265 & 0.391 & $-0.126 * * *$ & $p<0.001$ \\
\hline у 2009-2015 & 0.290 & 0.218 & 0.448 & $-0.230 * * *$ & $p<0.001$ \\
\hline Observations & 11,522 & 9,575 & 1,947 & & \\
\hline
\end{tabular}

Sources Calculated based on CHNS 1989-2015

Note Age is limited from 20 to 44 


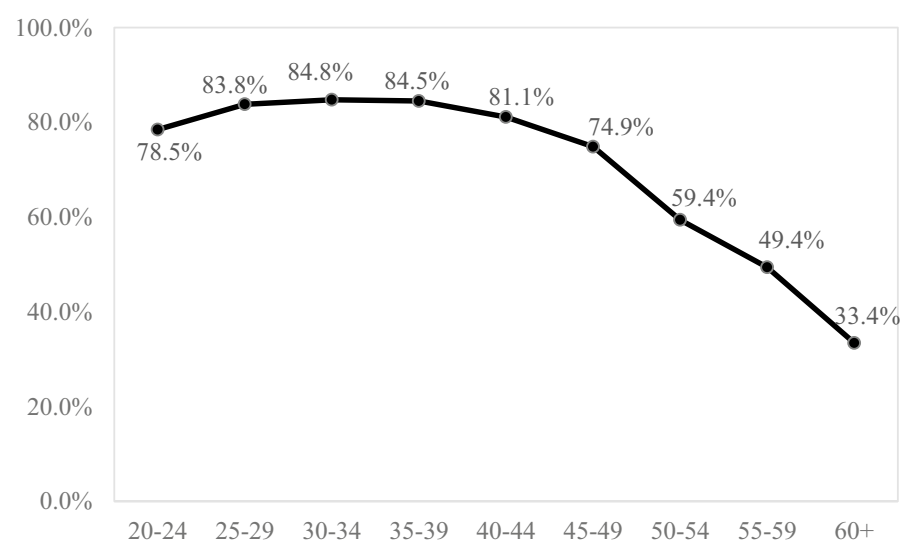

Fig. 2.1 Female employment rate by age. Source Calculated based on CHNS 1989-2015

married women than for non-working group. Therefore, analyses should control for these factors.

Figure 2.1 shows the female employment rate (percentage of working women to total samples in each age group) by age group. First, the female employment rate is maintained at a higher level (around 80\%) for Chinese married women aged 25-39. In Japan and Korea, the female employment rate by age group is an M-shaped curve that is lowest in the period of marriage and child care (Ma 2011). This indicates that the negative effect of child care on maternal employment may be smaller in China than in Japan and Korea.

Second, although the employment rate for married women aged 25-44 is maintained at around $80 \%$, it decreases greatly for married women aged 50 and older. Concretely, the employment rates are $59.4 \%, 49.4 \%$ and $33.4 \%$ for married women aged 50-54, 55-59, and older than 60 years, respectively. The results can be explained by China's mandatory retirement system. In the public sector (e.g., government organizations, SOEs), the mandatory retirement age is 50 years for female workers (bluecollar workers) and 55 years for female cadres (white-collar workers), which causes a sharp decline of female employment rate for the group aged 50 and over.

\subsubsection{Female Employment Rate by Age and Education}

The female employment rate by age and education groups are shown in Fig. 2.2. It is observed that, in general, the employment rate is higher for the low-education group than for both the middle-level group and the high-level education group. In addition, for married women aged 55 and older, the female employment rate is lower for the highly educated group than for both the low- and middle-level education groups. 


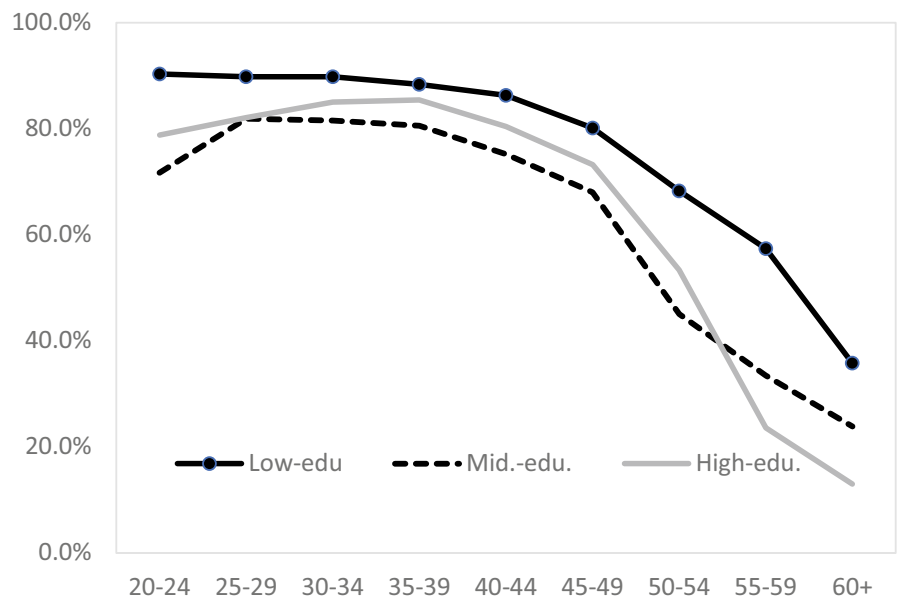

Fig. 2.2 Female employment rate by age and education. Source Calculated based on CHNS 19892015. Note High_edu.: college and over; Mid-edu.: senior high school or junior high school; Low_edu.: primary school and lower

The explanation is as follows. Based on the marriage-matching model, the probability of marrying a well-educated man is higher for a well-educated woman than for a woman with low-education level. According to the human capital theory (Becker 1964; Mincer 1974), the total household income may be lower for low-education women than for highly educated women; therefore, low-education married women must work more in the labor market to support their families. In addition, most highly educated married women age 55 and older retire from the public sector and receive higher pension benefits, which may cause the female employment rate decreased.

\subsubsection{Female Employment Rate by Age and Unearned Income}

The female employment rate by age and unearned income group is shown in Fig. 2.3. The unearned income groups include the low-income group (first tertile), the middleincome group (second tertile), and the high-income group (third tertile) based on their husband's income. It can be observed that, in each age group, the female employment rate is lowest for the high-income group, while it is highest for the low-income group. 


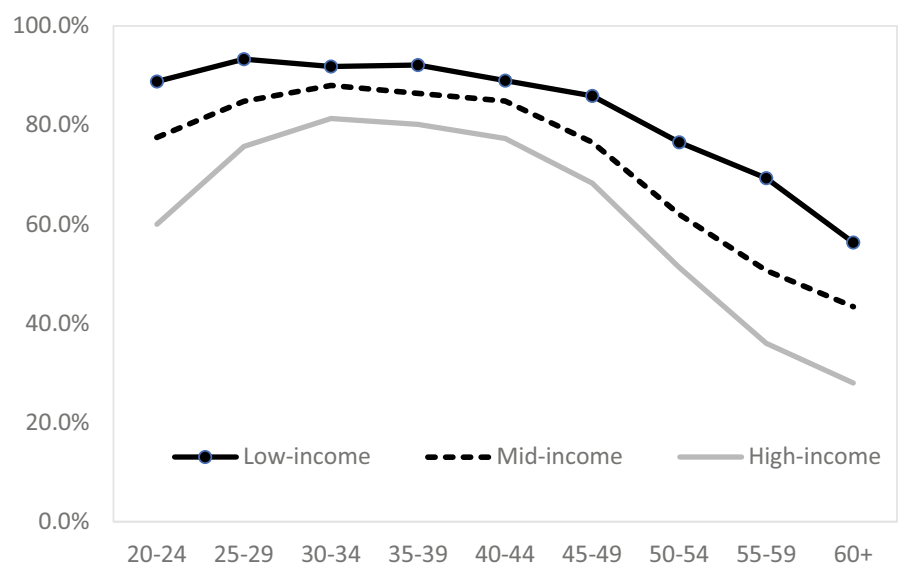

Fig. 2.3 Female employment rate by age a and unearned income. Source Calculated based on CHNS 1989-2015. Note Non-earning income = husband income; Low-income: first tertile; Mid-income: second tertile; High-income: third tertile

\subsubsection{Female Employment Rate by Age and Number of Children}

The female employment rate by age and number of children is shown in Fig. 2.4. We calculated for three groups-women with one child, two children, and three or more children. First, the female employment rate is highest for the group with three or more children. Second, the differential of employment rate is small between women with one child and those with two children. This indicates that mothers with

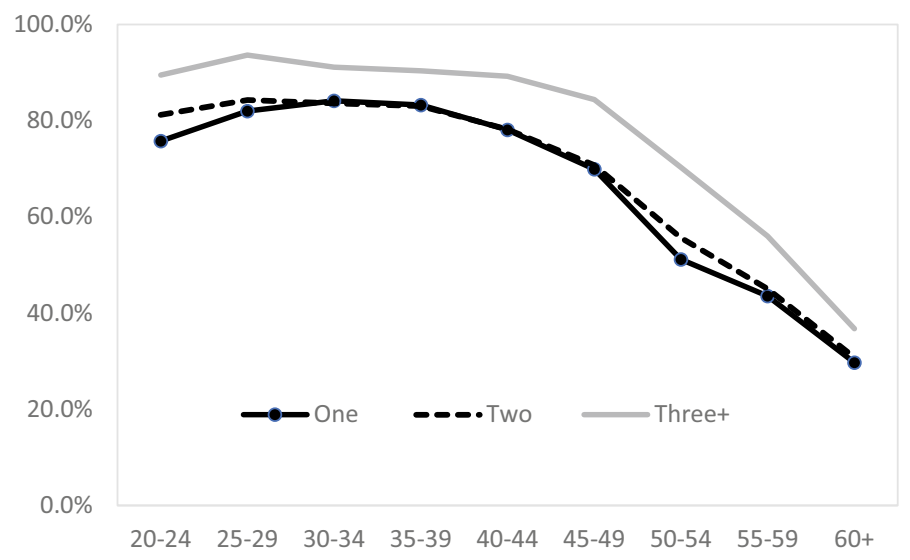

Fig. 2.4 Female employment rate by age and number of children. Source Calculated based on CHNS 1989-2015 
more children (three or more) are likely to work. The differentials of employment rate between mothers with one child and those with two indicates that the negative influence of child care on maternal employment is small. Regarding the influences of China's population policies, the analyzed period in this study is from 1989 to 2015 , while the one-child policy was implemented in 1979, and the two-child policy was implemented in 2016. Thus, the effects of the current period's two-child policy on maternal employment should be evaluated in the future by using new survey data after 2016.

To summarize, it is observed that the female employment rate differs by age, education level, unearned income level, and number of children. It should be noticed that these are results when other factors are not controlled. The effects of the market wage, the reservation wage, and unearned income estimated by econometric analyses after controlling for other factors that might affect women's choice to work are reported as follows.

\subsection{Econometric Analysis Results}

\subsubsection{The Market Wage, Child Care, Unearned Income, and Work Participation of Married Women in China}

Table 2.2 presents the estimation results of the probability of participation in work by using the probit regression model and random effects (RE) probit regression models. The likelihood ratio (LR) test indicates that the RE probit model is appropriate. The new findings based on RE probit model results can be summarized as follows.

First, it is shown that the market wage positively affects the probability of work participation of married women; the probability of participation in work increases as the market wage rises. These results are consistent with those of Layard et al. (1980), Franz and Kawasaki (1981), and Zabalza (1983) for developed countries. This indicates that when the market wage rises, the substitution effect is greater than the income effect, which increases the employment probability of married women in China.

Second, the reservation wage negatively affects the work participation of married women. Concretely, as compared with a mother with one child, the probability of participation in work is lower for a mother with two or more children. As compared with a mother with a child aged $0-1$, the probability of participation in work is higher for a mother with a child aged $4-5$ or 6-14. These results are consistent with those of Hofferth (1984), Waite et al. (1985), O'Connell and Bloom (1987), Wenk and Garrett (1992), Del Boca et al. (2004), Buckles (2008), and Miller (2011) for developed countries and Zhang (2011) and Yang and Bai (2017) for China.

As compared with the results of Ma (2009a, b), who reported the influence of the age of youngest child on the employment of married women is not significant, the negative effect of child care on maternal employment is suggested to have increased 
Table 2.2 Probability of participation in work of married women in China

\begin{tabular}{|c|c|c|c|c|}
\hline & \multicolumn{2}{|l|}{ Probit } & \multicolumn{2}{|l|}{ Probit_RE } \\
\hline & Coef. & S.E. & Coef. & S.E. \\
\hline Imputed wage & $0.384 * * *$ & 0.152 & $0.506^{* *}$ & 0.202 \\
\hline \multicolumn{5}{|c|}{ Number of children (One) } \\
\hline Two & $-0.182 * * *$ & 0.046 & $-0.228 * * *$ & 0.064 \\
\hline Three and more & $-0.152 * *$ & 0.064 & $-0.195 * *$ & 0.088 \\
\hline \multicolumn{5}{|c|}{ Age of youngest child (Age 0-1) } \\
\hline Age $2-3$ & 0.136 & 0.089 & 0.162 & 0.109 \\
\hline Age 4-5 & $0.223 * *$ & 0.089 & $0.244 * *$ & 0.108 \\
\hline Age 6-14 & $0.148 * *$ & 0.072 & $0.152 *$ & 0.089 \\
\hline Age 15 and over & -0.066 & 0.079 & -0.122 & 0.101 \\
\hline Unearned income & -0.011 & 0.018 & -0.013 & 0.023 \\
\hline Minority ethnicity & -0.043 & 0.061 & -0.060 & 0.085 \\
\hline Urban & $0.309 * * *$ & 0.051 & $0.393 * * *$ & 0.071 \\
\hline \multicolumn{5}{|l|}{ Region (East) } \\
\hline Central & $-0.255^{* * *}$ & 0.058 & $-0.328 * * *$ & 0.081 \\
\hline West & $0.120 *$ & 0.073 & 0.130 & 0.099 \\
\hline Northeast & $-0.399 * * *$ & 0.062 & $-0.491 * * *$ & 0.088 \\
\hline \multicolumn{5}{|c|}{ Period (y 1989-1997) } \\
\hline у $2000-2006$ & $-1.051 * * *$ & 0.191 & $-1.350 * * *$ & 0.257 \\
\hline y 2009-2015 & $-1.455 * * *$ & 0.310 & $-1.849 * * *$ & 0.416 \\
\hline Constants & -1.004 & 1.216 & -1.448 & 1.620 \\
\hline Observations & \multicolumn{2}{|l|}{11,522} & \multicolumn{2}{|l|}{11,522} \\
\hline Groups & \multicolumn{2}{|l|}{+2} & \multicolumn{2}{|l|}{4,920} \\
\hline Log likelihood & \multicolumn{2}{|l|}{$\begin{array}{l}-2585.964 \\
0.082\end{array}$} & \multicolumn{2}{|l|}{-2535.901} \\
\hline LR test of rho $=0$ : & & & $\begin{array}{l}\text { chibar2 }(01) \\
\text { Prob }>=\text { ch }\end{array}$ & $\begin{array}{l}.13 \\
=0.000\end{array}$ \\
\hline
\end{tabular}

Source Calculated based on CHNS 1989-2015

Notes $* * * p<0.01, * * p<0.05, * p<0.10$

in the current period over that in the past. This indicates that the family-work conflict problem has grown worse with the progress of the market-oriented economy reform. The results can also be explained by the fact that, as the economic development and the household income increased, some married women choose to become housewives and exit the labor market voluntarily.

Third, the effect of unearned income is not statistically significant. Although the results in Fig. 2.4 show that the female employment rate is lowest for the high-income group and higher for the low-income group, it seems likely that a husband's income may negatively affect their wife's work participation. However, when the other factors 
are controlled, the effect of husbands' incomes on their wives' employment is not significant in China. The finding contrasts with those of most studies of developed countries. This may be caused by the fact that gender equality in workplace and family has been promoted by the government since the planned economy period; thus, most married women are willing to work and they are independent of their husbands' incomes.

Fourth, other factors also affect the probability of participation in work of married women. (1) The probability of participation in work is higher for urban women than for rural women. (2) As compared with women in the central and northeast regions, women in the eastern region are more likely to work. This may result from the fact that, when women in urban areas or regions in which the level of economic development is higher (eastern regions), better chances for jobs may increase the probability of working. (3) As compared with the past period (the period of 19891997), the probability of participation in work decreased in the current period (the periods of 2000-2006 and 2009-2015). This is confirmed by the fact that female labor force participation rate decreased during the market-oriented economy reform period.

\subsubsection{Results by Group}

To examine the heterogeneity problem between various groups, a set of subsamples was used. We mainly summarized the findings about the market wage, child care, and husband's income in the following.

\section{(1) Results by Age}

The results for three age groups-aged 20-29, 30-39, and 40-49-are shown in Table 2.3. First, the market wage positively affects the employment of women aged 20-29 and 30-39 $(2.162,0.693$, respectively), while the effect is negative for those aged 40-49. These results are significant at 1 and 5\% levels. This suggests that the effect of the market wage on the employment of married women differs by age group; the market wage has a negative effect for middle-aged married women, while it has a positive effect for younger married women. These results are similar to those of Dooley (1982), who found that the market wage positively affects the employment of black married women aged 30-34, while its effect is negative for black married women aged 35-39 and 40-44.

Second, regarding the effect of the reservation wage, (1) for younger mothers (the group aged 20-29), the influence of both the number of children and the age of the youngest child on the employment of married women are not significant. In contrast, for married women aged 30-39 and 40-49, as compared with a mother with one child, the probability of participation in work is lower for a mother with two children. (2) For married women aged 30-39, as compared with a mother with a child aged $0-1$, a mother with a child aged $4-5$ or $6-14$ years is more likely to 
Table 2.3 Results by age

\begin{tabular}{|c|c|c|c|c|c|c|}
\hline & \multicolumn{2}{|c|}{ (1) Age 20-29 } & \multicolumn{2}{|c|}{ (2) Age 30-39 } & \multicolumn{2}{|c|}{ (3) Age 40-49 } \\
\hline & Coef. & S.E. & Coef. & S.E. & Coef. & S.E. \\
\hline Imputed wage & $2.162 * * *$ & 0.783 & $0.693 * *$ & 0.304 & $-0.795 * * *$ & 0.239 \\
\hline \multicolumn{7}{|c|}{ Number of children (One) } \\
\hline Two & 0.135 & 0.210 & $-0.312 * * *$ & 0.093 & $-0.246 * * *$ & 0.072 \\
\hline More than three & 0.029 & 0.355 & $-0.234 *$ & 0.136 & -0.133 & 0.089 \\
\hline \multicolumn{7}{|c|}{ Age of youngest child (Age $0-1)$} \\
\hline Age 2-3 & 0.068 & 0.201 & $0.308 *$ & 0.170 & 0.771 & 0.564 \\
\hline Age 4-5 & 0.111 & 0.222 & $0.577 * * *$ & 0.166 & 0.589 & 0.485 \\
\hline Age 6-14 & 0.291 & 0.282 & $0.417 * * *$ & 0.139 & $0.710 *$ & 0.431 \\
\hline Age 15 and over & & & 0.163 & 0.174 & 0.444 & 0.430 \\
\hline Unearned income & -0.096 & 0.084 & -0.042 & 0.034 & 0.005 & 0.025 \\
\hline Minority ethnicity & -0.086 & 0.283 & 0.002 & 0.119 & 0.013 & 0.096 \\
\hline Urban & $0.695 * *$ & 0.284 & $0.425 * * *$ & 0.102 & -0.002 & 0.073 \\
\hline \multicolumn{7}{|l|}{ Region (East) } \\
\hline Central & $-0.532 *$ & 0.308 & $-0.267 * *$ & 0.112 & $-0.333 * * *$ & 0.082 \\
\hline West & -0.028 & 0.347 & $0.257 *$ & 0.140 & 0.122 & 0.103 \\
\hline Northeast & $-1.140 * * *$ & 0.359 & $-0.461 * * *$ & 0.121 & $-0.275 * * *$ & 0.092 \\
\hline \multicolumn{7}{|c|}{ Period (y 1989-1997) } \\
\hline у 2000-2006 & $-3.790 * * *$ & 1.089 & $-1.612 * * *$ & 0.383 & 0.346 & 0.298 \\
\hline у 2009-2015 & $-6.059 * * *$ & 1.745 & $-2.187 * * *$ & 0.623 & $0.900 *$ & 0.482 \\
\hline Constants & $-12.687 * *$ & 5.863 & -2.938 & 2.456 & $8.239 * * *$ & 2.027 \\
\hline Observations & \multicolumn{2}{|l|}{2,123} & \multicolumn{2}{|l|}{5,819} & \multicolumn{2}{|l|}{6,797} \\
\hline Groups & \multicolumn{2}{|l|}{1,534} & \multicolumn{2}{|l|}{3,331} & \multicolumn{2}{|l|}{3,645} \\
\hline Log likelihood & \multicolumn{2}{|l|}{-366.48} & \multicolumn{2}{|l|}{-1162.84} & \multicolumn{2}{|l|}{-2274.46} \\
\hline LR test of rho $=0$ : & \multicolumn{2}{|c|}{$\operatorname{chibar} 2(01)=17.33$} & \multicolumn{2}{|c|}{ chibar $2(01)=25.65$} & \multicolumn{2}{|c|}{ chibar $2(01)=71.81$} \\
\hline Prob $\geq$ chibar2 & \multicolumn{2}{|c|}{0.000} & \multicolumn{2}{|l|}{0.000} & \multicolumn{2}{|c|}{0.000} \\
\hline
\end{tabular}

Source Calculated based on CHNS 1989-2015

Note (1) *** $p<0.01, * * p<0.05, * p<0.10$

(2) Random effects probit regression model is used

work; while the influences of the age of the youngest child on the labor supply are not significant for mothers aged 20-29 and those aged 40-49. The negative effect of child care seems to be greater for mothers aged 30-39 who are in an important period of career development. This suggests that the family-work conflict problem may worse for married women aged 30-39 years.

Third, the effect of the husband's income is not significant in each age group, which confirms the conclusions shown in Table 2.2 by using total samples. 


\section{(2) Results by Urban and Rural Areas}

Table 2.4 summarizes the results by urban areas and rural areas. First, the effect of the market wage on the labor supply differs by area (urban or rural). The market wage positively affects the labor supply of married women in urban areas, while the influence is not significant for married women in rural areas. This may be caused by the fact that the function of the market mechanism is weaker in rural areas than in urban areas; therefore, the influence of the market wage on the labor supply is smaller for married women in rural areas. It also can be explained by differences in gender role consciousness among urban and rural areas. The influence of Confucianism

Table 2.4 Results by urban areas and rural areas

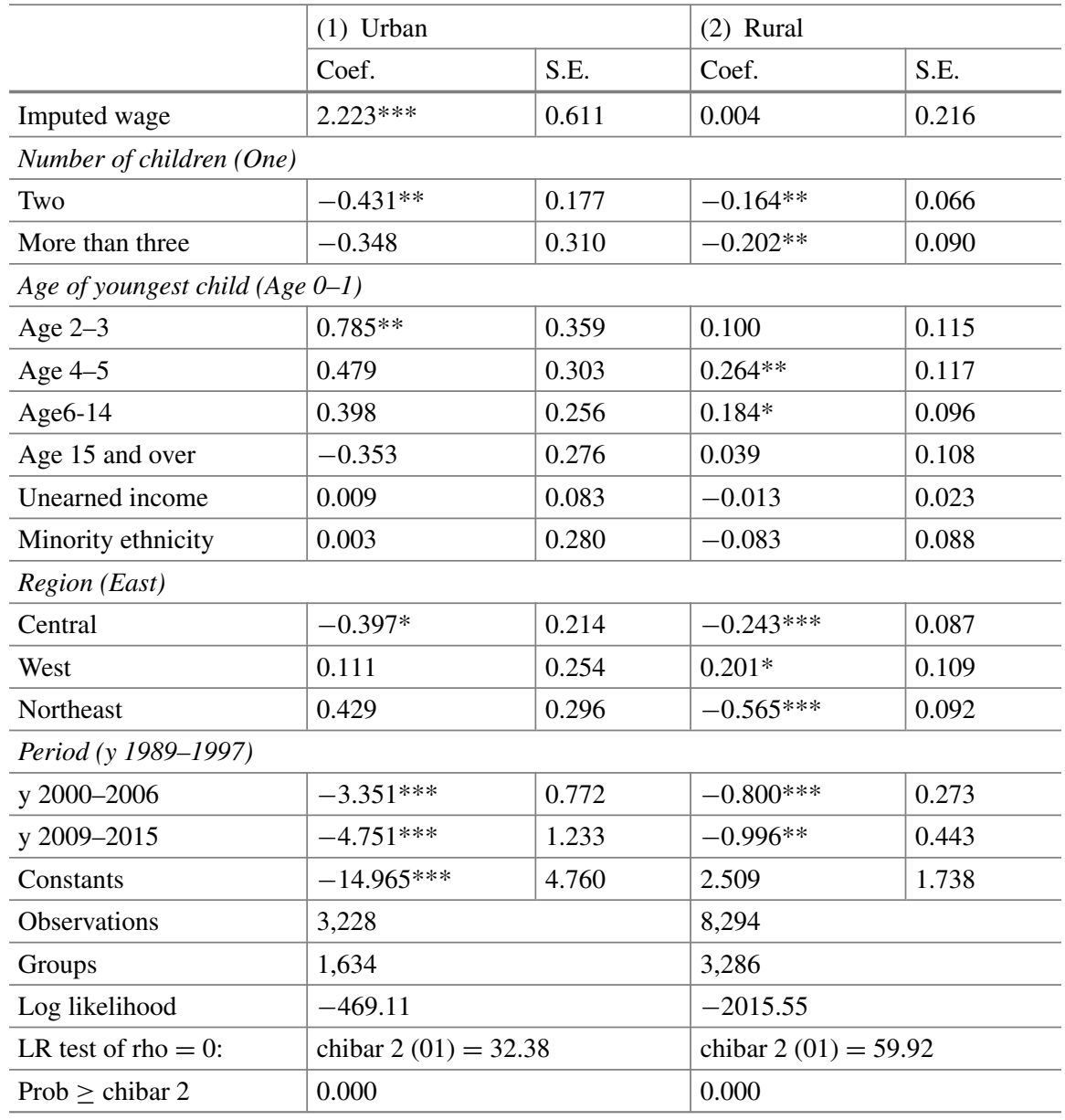

Source Calculated based on CHNS 1989-2015

Note: (1) *** $p<0.01, * * p<0.05, * p<0.10$

(2) Random effects probit regression model is used 
is greater in rural areas (Cheng 2011; Fen and Xiao 2014), and gender wage gap is larger in rural areas (Iwasaki and Ma 2020); therefore, the impact of economic factors-such as the market wage on the employment of rural women-is smaller.

Second, for the effect of reservation wage, (1) for both urban and rural areas, as compared with a mother with one child, the probability of participation in work is lower for a mother with two or more children. (2) Having a child aged 0-1 negatively affects mothers' labor supply for both urban and rural areas. This suggests that child care negatively affects the employment of married women in both urban and rural areas. When we compare the sizes of the coefficients, the negative effect of child care is greater in urban areas than rural areas.

Third, for both urban and rural areas, the effects of a husband's income are not significant, which confirmed the conclusions shown in Table 2.2 by using total samples.

\subsubsection{Considering Irregular Work and Regular Work}

Regarding the choice of employment status, we used analyses for choosing regular work and irregular work. The results on employment status are summarized in Table 2.5.

There is no common definition of irregular work in previous studies, and the classification of regular work or irregular work is usually based on the number of hours worked, labor contract, or occupation type (i.e. Zhang and Qin 2015; Zhang et al. 2018). In this study, irregular work is defined by the type of occupation, as in the CHNS questionnaire. Irregular workers include self-employed workers with no employees (including farmers), temporary workers, and paid or unpaid family workers. Regular workers include self-employed workers who employ others, those who work for others or work in units (enterprises or organizations) as permanent employees, or workers with a long-term labor contract.

Two models-(i) a multinomial probit regression model and (ii) a random effects probit regression model-are used. The dependent variables are a category variable $(1=$ nonwork, $2=$ irregular work, $3=$ regular work $)$ in the multinomial probit regression model, and a binary variable $(1=$ irregular or regular worker, $0=$ nonworker $)$ in the random effects probit regression model. The results by using these two types of model are similar. Regarding the heterogeneity problem, we summarize the findings based on the results of the random effects model as follows.

First, the effect of the market wage differs by whether a person works regularly or irregularly. Concretely, the market wage positively affects the probability of becoming a regular worker, while when the market wage rises, the probability of becoming an irregular worker is lower than that of becoming a nonworker. This suggests that the substitution effect is greater for regular work, while the income effect is greater for irregular work. This can be explained by the labor market's segmentation into a formal and informal sector. Working hours are longer and the social security is not maintained for workers in the informal sector; therefore, although the 


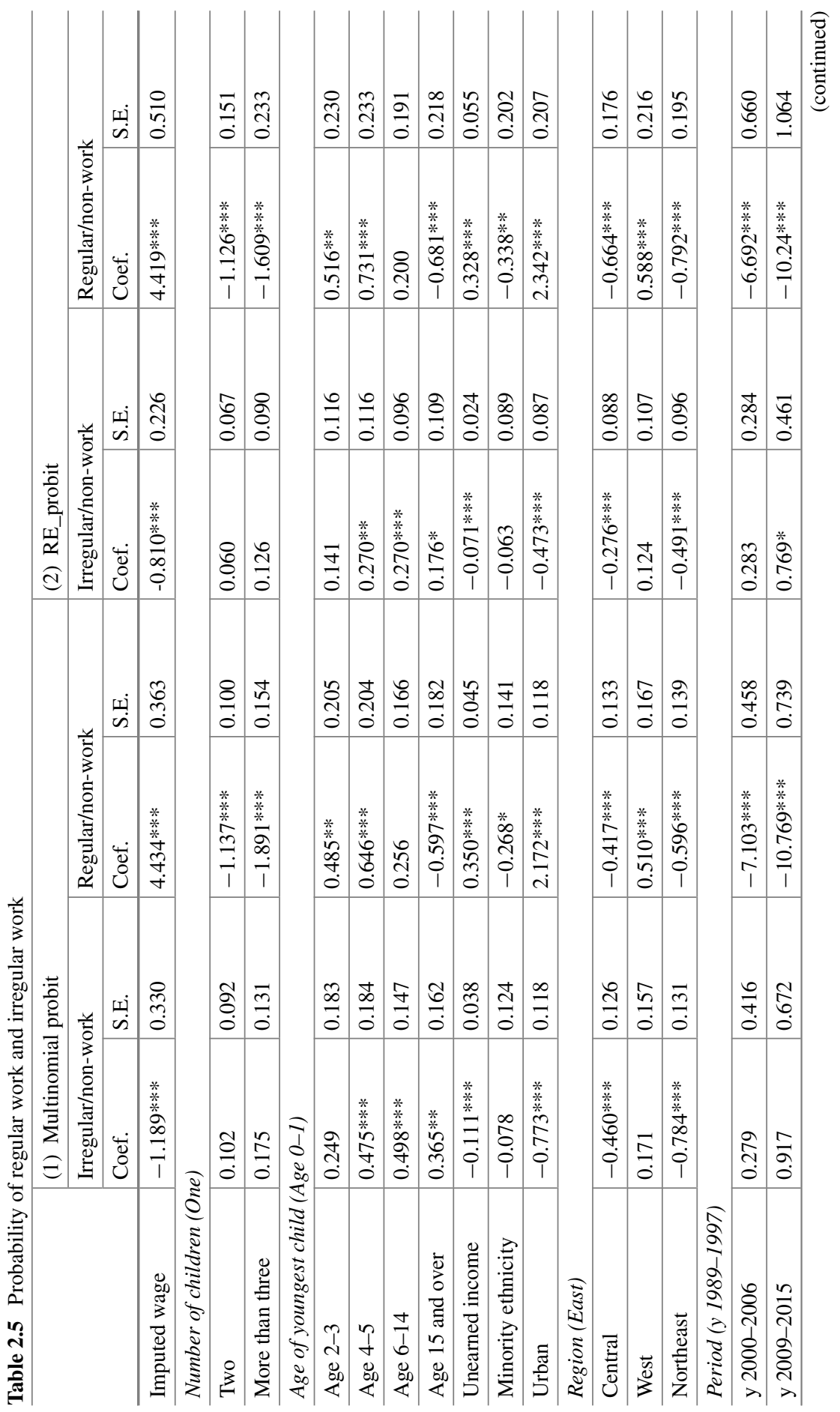




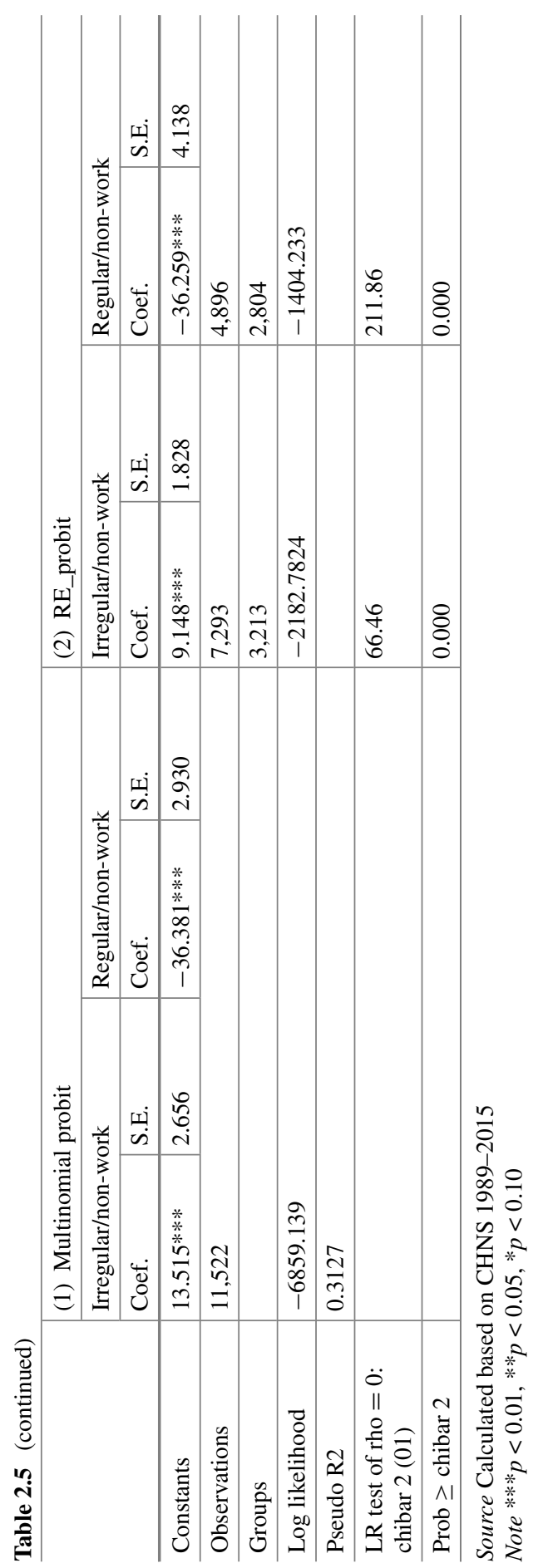


market wage may be higher than the reservation wage, the probability of becoming an irregular worker is lower (Ma 2016).

Second, for the effects of child care, (1) the probability of becoming a regular worker decreases for a mother with more than two children, while the impact of the number of children on irregular work is not significant. (2) The age of the youngest child affects the probability of both regular work and irregular work. As compared with a mother with a younger child (e.g., a child aged 0-1), the probability of becoming an irregular worker or a regular worker is higher for a mother with an older child (e.g., a child aged 4-5 or a child aged 15 and over). To compare the size of the age of child dummy variables, the effect of the youngest child's age is greater for regular work. It is observed that the negative effect of child care is greater for regular work. This can be explained as follows. From the labor supply side, the labor supply (e.g., working hours) of irregular workers can be more easily adjusted for (e.g., the self-employed). It is pointed out that irregular work may reduce the work-family conflict. Therefore, the negative effect of child care on the labor supply of married women is smaller for irregular workers than for regular workers.

Third, the results show an interesting finding for the effect of the husband's income. The husband's income positively affects the probability of becoming a regular worker, while it negatively affects the probability of becoming an irregular worker. These results about regular work can be explained by the marriage-matching model. The probability is high that a married, well-educated man who earns a high income will marry a well-educated woman who is likely to become a regular worker. For irregular workers, when the income constraint is held constant, if the unearned income increases, the labor supply may be reduced if leisure is a superior good.

\subsection{Conclusions}

Using the longitudinal survey data of CHNS from 1989 to 2015, this study analyzes the impact of the market wage, the reservation wage, and unearned income on the probability married women will work. The random effects model is used to address the heterogeneity problem. The main findings and policy implications are as follows.

First, in general, (1) the market wage positively affects the employment of married women; the probability of participation in work increases as the market wage rises. These results are consistent with those of previous empirical studies for developed countries. (2) The reservation wage (here, the number of children and age of the youngest child) negatively affects the employment of married women. (3) The effect of unearned income is not statistically significant, which contrasts with the findings of most studies for developed countries.

Second, the effects differ by age. (1) The market wage has a negative effect for middle-aged married women aged 40-49, while it has a positive effect for younger married women, aged 20-39. (2) The negative effect of child care is greater for mothers aged 30-39. (3) The effect of a husband's income is not significant in any age group. 
Third, the effects differ in urban and rural areas. (1) The market wage positively affects the employment of married women in urban areas, while the influence of the market wage on married women is not significant for in rural areas. (2) The negative effect of the reservation wage is greater for married women in urban areas than those in rural areas. (3) For both urban and rural areas, the effects of a husband's income are not significant.

Fourth, for the effects by employment status, (1) the market wage positively affects the probability of becoming a regular worker; when the market wage rises, the probability of becoming an irregular worker is lower than the probability of becoming a nonworker. (2) The negative effect of the reservation wage is greater for regular work. (3) The husband's income positively affects the probability of becoming a regular worker, while it negatively affects the probability of becoming an irregular worker.

The results indicate that child care negatively affects the employment of married women, particularly for women aged 30-39 who are in an important period of career development, and for women in urban areas. As compared with irregular work, the negative effect of child care is greater for regular work. This suggests that as the economy system transitions from a planned economy to a market-oriented economy, the problem of family-work conflict increased, particularly for regular female workers. This may due to the decrease of child care support from firms and government (Maurer-Fazio et al. 2011; Connelly et al. 2018). A child care support policy should be implemented by the Chinese government. The child care support policy can be expected to increase both the total fertility rate and the female labor force participation rate, which contributes to long-term economic growth.

The market wage was found to positively affect the employment of married women, particularly for younger married women aged 20-39, married women in urban areas, and regular workers. This suggests that the influence of the market mechanism on the labor supply of married women has increased with the progress of the market-oriented economy reform. However, it should be noted that the market wage negatively affects the probability of becoming an irregular worker. The result is related to the Chinse labor market segmentation by formal and informal sectors (Zhang and Qin 2015; Ma 2016; Zhang et al. 2018). The number of regular workers has decreased, but the number of irregular workers has increased in the current period. For example, the proportion of female irregular workers to total female workers increased from 33.9\% in 1996 to 68.6\% in 2010 (Zhang and Hu 2017). As compared with the regular worker group, irregular workers usually earn a lower wage and fewer fringe benefits. Their social security entitlement is poorer, and their probability of becoming unemployed is higher (Ma 2008, 2009a, b, 2011; Wu 2009). Labor and social security policies should be implemented to reduce the gap between the formal and informal sectors.

Finally, it should be noted that this study has limitations. First, although we used RE models to address the heterogeneity problems in the current study, our future research will address the endogeneity problem between child care, husband's income, and labor supply by using other econometric models such as the instrument variable methods. Second, the dynamic model of labor supply should be employed based on 
a life-cycle model. Third, for the reservation wage, parent care should be considered; we analyzed the issue in Chap. 3 of this book. Fourth, the effect of these economic factors on working hours has become an issue for our future research. Despite these limitations, we believe that the current study, which takes full advantage of longitudinal survey data, can provide new insight for understanding the association between the market wage, child care, husband's income, and the employment of married women in China under the market-oriented economy reform period. This may add to the evidence of the determinants of the women' employment in China.

\section{Notes}

1. Since the 1990s, employment adjustment has been promoted in SOEs. Many significant employees became unemployed. According to the China Labor Statistics Yearbook 2000, about 5 million urban workers were restructured from 1996 to 2000. Ma (2008) and Li (2003) pointed out that the gender gap in the employment adjustment of SOEs was maintained, and the disadvantage of SOE reform is greater for female workers than for male workers. For the analysis of ownership sector and the gender wage gap, please refer to Chap. 4 of this book.

2. The one-child policy was China's family planning policy, which consisted of a set of regulations, including restrictions on the number of children per household and the minimum marriage age. The one-child policy mostly applied to urban residents and public sector employees. In rural regions, if the first child was a girl, a second child was permitted. If both the wife and husband were Chinese citizens returning from abroad, if both the wife and husband are without siblings, and for ethnic minorities, a second child was permitted (Hesketh et al. 2005; Wang et al. 2013). This policy was published in 1979 and abolished in October 2015.

3. In order to address the potential consequences of the one-child policy, such as the aging population and labor shortages, the one-child policy was replaced by the universal two-child policy in October 2015. Based on the new policy, a married woman can have two children. The new law came into force on January 1, 2016.

4. For a detailed survey of the effects of the market wage, the reservation wage, and unearned income on women's labor supply, please refer to Smith (1980), Killingsworth and Heckman (1986), Goldin (1990), and Blundell and MaCurdy (1999).

5. Some previous studies for China explore only the influence of irregular work on childbearing based on the descriptive statistical results (for example, Ding and Shi 2016 and Zhang and $\mathrm{Hu}$ 2017).

6. The values of female employment rate in Figs. 2.2, 2.3 and 2.4 are summarized in Appendix Tables 2.7, 2.8 and 2.9. 


\section{Appendix}

See Tables 2.6, 2.7, 2.8 and 2.9.

Table 2.6 Results of wage function

\begin{tabular}{|c|c|c|c|c|}
\hline & \multicolumn{2}{|c|}{ (1) One-step } & \multicolumn{2}{|c|}{ (2) Two-step } \\
\hline & \multicolumn{2}{|c|}{ Probability of work } & \multicolumn{2}{|c|}{ Wage function } \\
\hline & Coef. & S.E. & Coef. & S.E. \\
\hline Wife's years of schooling & $0.121 * * *$ & 0.005 & $0.058 * * *$ & 0.006 \\
\hline Experience year & 0.032 & 0.029 & -0.013 & 0.012 \\
\hline Exp. sq. & -0.000 & 0.000 & $0.001 * *$ & 0.000 \\
\hline Minority ethnicity & -0.077 & 0.049 & 0.029 & 0.047 \\
\hline Husband income & $0.223 *$ & 0.137 & & \\
\hline Husband income_sq. & 0.004 & 0.008 & & \\
\hline Number of children & $-0.344 * * *$ & 0.023 & & \\
\hline Age of youngest child & 0.006 & 0.004 & & \\
\hline Urban & $1.038 * * *$ & 0.036 & $-0.193 * * *$ & 0.038 \\
\hline \multicolumn{5}{|l|}{ Region (East) } \\
\hline Central & $-0.440 * * *$ & 0.040 & $-0.151 * * *$ & 0.034 \\
\hline West & $-0.390 * * *$ & 0.045 & $-0.206 * * *$ & 0.039 \\
\hline Northeast & $-0.606 * * *$ & 0.045 & $-0.170 * * *$ & 0.041 \\
\hline \multicolumn{5}{|l|}{ Year (1989-1997) } \\
\hline 2000-2006 & $-0.320 * * *$ & 0.036 & $1.149 * * *$ & 0.033 \\
\hline 2009-2015 & 0.025 & 0.045 & $1.877 * * *$ & 0.033 \\
\hline Constant & $-3.278 * * *$ & 0.774 & $7.726 * * *$ & 0.173 \\
\hline adverse mills ratio & & & $-0.760 * *$ & 0.051 \\
\hline Observations & \multicolumn{4}{|l|}{11,711} \\
\hline Selected & \multicolumn{4}{|l|}{5,131} \\
\hline No-selected & \multicolumn{4}{|l|}{6,580} \\
\hline Prob > chi 2 & \multicolumn{4}{|l|}{0.000} \\
\hline
\end{tabular}

Source Calculated based on CHNS 1989-2015

Note $(1) * * * p<0.01, * * p<0.05, * p<0.10$

(2) Heckman two step model is used 
Table 2.7 Female employment rate by age and education group

Table 2.8 Female employment rate by age and husband income group

\begin{tabular}{l|l|l|l}
\hline & Low-edu (\%) & Mid-edu (\%) & High-edu (\%) \\
\hline $20-24$ & 90.3 & 71.7 & 78.8 \\
\hline $25-29$ & 89.8 & 81.9 & 82.1 \\
\hline $30-34$ & 89.8 & 81.5 & 85.0 \\
\hline $35-39$ & 88.4 & 80.5 & 85.4 \\
\hline $40-44$ & 86.3 & 75.2 & 80.4 \\
\hline $45-49$ & 80.1 & 68.0 & 73.2 \\
\hline $50-54$ & 68.3 & 45.0 & 53.3 \\
\hline $55-59$ & 57.4 & 33.5 & 23.6 \\
\hline $60+$ & 35.8 & 23.9 & 13.0
\end{tabular}

Source Calculated based on CHNS 1989-2015

\begin{tabular}{l|l|l|l}
\hline & Low-income (\%) & Mid-income (\%) & High-income (\%) \\
\hline $20-24$ & 88.8 & 77.5 & 60.0 \\
\hline $25-29$ & 93.3 & 84.8 & 75.7 \\
\hline $30-34$ & 91.8 & 88.0 & 81.3 \\
\hline $35-39$ & 92.1 & 86.4 & 80.2 \\
\hline $40-44$ & 89.0 & 84.9 & 77.3 \\
\hline $45-49$ & 85.9 & 76.6 & 68.3 \\
\hline $50-54$ & 76.6 & 62.0 & 51.3 \\
\hline $55-59$ & 69.3 & 50.6 & 36.0 \\
\hline $60+$ & 56.3 & 43.4 & 28.0 \\
\hline
\end{tabular}

Source Calculated based on CHNS 1989-2015

Table 2.9 Female employment rate by age and number of children group

\begin{tabular}{l|l|l|l}
\hline & One $(\%)$ & Two $(\%)$ & Three+ (\%) \\
\hline $20-24$ & 75.7 & 81.3 & 89.5 \\
\hline $25-29$ & 82.0 & 84.3 & 93.7 \\
\hline $30-34$ & 84.1 & 83.6 & 91.2 \\
\hline $35-39$ & 83.2 & 83.1 & 90.4 \\
\hline $40-44$ & 78.1 & 78.2 & 89.3 \\
\hline $45-49$ & 70.0 & 70.8 & 84.4 \\
\hline $50-54$ & 51.2 & 55.7 & 70.3 \\
\hline $55-59$ & 43.5 & 45.0 & 56.0 \\
\hline $60+$ & 29.7 & 30.8 & 36.7
\end{tabular}

Source Calculated based on CHNS 1989-2015 


\section{References}

Bardasi, E., \& Gornick, J. (2000). Women and part-time employment: Workers' “choices” and wage penalties in five industrialised countries. Iser Working Paper.

Becker, G. (1964). Human capital: A theoretical and empirical analysis, with special reference to education. New York: Columbia University Pres.

Blundell, R., \& Macurdy, T. (1999). Labor supply: A review of alternative approaches. In O. Ashenfelter \& D. Card (Eds.), Handbook of labor economics (Vol. 3A), Elsevier.

Blundell, R., \& Walker, I. (1982). Modelling the joint determination of household labour supplies and commodity demands. The Economic Journal, 92(366), 351-364.

Buckles, K. (2008). Understanding the returns to delayed childbearing for working women. American Economic Review, 98(2), 403-407.

Cheng, T. (2011). The determinants of gender role consciousness of Chinese women in rural regions: An empirical study based on Chinese General Survey. Journal of Chinese Women's Studies, 2011(1). (In Chinese).

Cogan, J. F. (1980a). Married women's labor supply: A comparison of alternative estimation procedures. In J. P. Smith (Ed.), Female labor supply: Theory and estimation. Princeton, N.J.: Princeton University Press.

Cogan, J. F. (1980b). Labor supply with costs and labor market entry. In J. P. Smith (Ed.), Female labor supply: Theory and estimation. Princeton, N.J.: Princeton University Press.

Connelly, R., Dong, X., Jacobsen, J., \& Zhao, Y. (2018). The care economy in post-reform China: Feminist research on unpaid and paid work and well-being. Feminist Economics, 24(2), 1-30.

Del Boca, D., Pasqua, S., \& Pronzato, C. (2004). Why are fertility and women's employment rates so low in Italy? Lessons from France and the U.K (IZA Discussion Papers 1274). Institute for the Study of Labor (IZA).

Ding, Y., \& Shi, H. (2016). Issues of urban female informal employment in New Era. Population and Society, 2, 32-38. (In Chinese).

Dooley (1982) Labor supply and fertility of married women: An analysis with grouped and individual data from the 1970 U.S. Census. Journal of Human Resources, 17(4), 499-532.

Drobnic, S., Blossfeld, H. P., Rohwer, G., \& Wittig, I. (1996). Women's part-time work: Reconciliation between family and employment? A comparison between Germany and the USA. Bremen: Universität Bremen, SFB 186. http://nbn-resolving.de/urn:nbn:de:0168-ssoar-57389.

Fen, X., \& Xiao. J. (2014). The differences of gender role consciousness of Chinese women between the rural regions and urban regions. Journal of Humanities, 2014(11). (In Chinese).

Franz, W., \& Kawasaki, S. (1981). Labor supply of marriage women in the Federal Republic of Germany: Theory and empirical results from a new estimation procedure. Empirical Economics, 6(2), 129-143.

Goldin, C. (1990). Understanding the gender gap: An economic history of American women. New York: Oxford University Press.

Gustafsson, B., \& Li, S. (2000). Economic transformation and the gender earnings gap in urban China. Journal of Population Economics, 13(2), 305-329.

Hanoch, G. (1980) A multivariate model of labor supply: Methodology and estimation. In J. P. Smith (Ed.) Female labor supply: Theory and estimation. Princeton, N.J.: Princeton University Press.

Heckman, J. J. (1976). The common structure of statistical models of truncation, sample selection, and limited development variables and a simple estimator for such model. Annals of Economic and Social Measurement, 5(4), 475-492.

Heckman, J. J. (1979). Sample selection bias as a specification error. Econometrica, 47(1), 153-161.

Heckman, J. J., \& MaCurdy, T. E. (1980). A life cycle model of female labor supply. Review of Economic Studies, 47(1), 47-74.

Hesketh, T., Lu, L., \& Xing, Z. W. (2005). The effect of China's one-child family policy after 25 years. New England Journal of Medicine, 353(11), 1171-1176. 
Hofferth, S. L. (1984). Long-term economic consequences for women of delayed childbearing and reduced family size. Demography, 21(2), 141-155.

Iwasaki, I., \& Ma, X. (2020). The gender wage gap in China: A Large meta-analysis. Journal for Labor Market Research, 54, 17. (Online early). https://doi.org/10.1186/s12651-020-00279-5.

Jia, N., Gan, L., \& Zhang, J. (2013). Wage rate, the mommy trap and unobserved types. Economic Research Journal, 5, 61-72. (In Chinese).

Killingsworth, M. R., \& Heckman, J. J. (1986) Female labor supply: A survey. In O. Ashenfelter, $\&$ D. Card (Eds.) Handbook of labor economics (Vol. 1). Amsterdam: North Holland; New York: Sole Distributors for the U.S.A. and Canada, Elsevier Science.

Layard, R., Barton, M., \& Zabalza, A. (1980). Marriage women's participation and hours. Economica, 47(185), 51-72.

Li, H. (2003). Economic transition and returns to education in China. Economics of Education Review, 22(3), 317-328.

Ma, X. (2008). A comparison of the wage differentials in regular and irregular sectors between Japan and China. The Journal of Ohara Institute for Social Research, 601, 7-28. (In Japanese).

Ma, X. (2009a). An empirical study on married women' labor supply in urban China. Asian Studies, 55(3), 35-54. (In Japanese).

$\mathrm{Ma}, \mathrm{X} .(2009 \mathrm{~b})$. A comparison of the wage differentials in regular and irregular sectors between Japan and China. The Journal of Ohara Institute for Social Research, 602, 86-98. (In Japanese).

Ma, X. (2011). Female labor force participation in China: Marketization and changes in urban labor market. Tokyo: Keio University Press. (In Japanese).

Ma, X. (2016). Economic transition and the determinants of self-employment in urban China: 2007-2013. Journal of Chinese Economic and Business Studies, 14(3), 279-230.

Ma, X. (2018a). Economic transition and labor market reform in China. Singapore: Palgrave Macmillan.

Ma, X. (2018b). Ownership sector segmentation and gender wage gap in urban China during the 2000s. Post-Communist Economies, 30(6), 775-804.

Maurer-Fazio, M., Connelly, R., Chen, C. L., \& Tang, L. (2011). Childcare, eldercare, and labor force participation of married women in urban China, 1982-2000. Journal of Human Resources, 46(2), 261-294.

Miller, A. R. (2011). The effects of motherhood timing on career path. Journal of Population Economics, 24(3), 1071-1100.

Mincer, J. (1974). Schooling, experience, and earnings. New York: Columbia University Press.

Nakamura, M. A., Nakamura, M., \& Cullen, D. (1980). Job opportunities, the offered wage, and the labor supply of marriage women. American Economic Review, 69(5), 787-805.

Nakamura, A., \& Nakamura, M. (1981). A comparison of the labor force behavior of married women in the United States and Canada, with special attention to the impact of income taxes. Econometrica, 49(2), 451-490.

National Bureau of Statistics (NBS). (2019). China statistical yearbook. Beijing: China Statistics Press.

O'Connell, M., \& Bloom, D. E. (1987). Juggling jobs and babies: America's child care challenge, population trends and public policy, number 12. Washington, DC: Population Reference Bureau.

Pan, J. (2002). Female employment and social security in China during the economic transition. Management World, 7, 59-68. (In Chinese).

Schulz, T. P. (1980). Estimating labor supply function for married women. In J. P. Smith (Ed.), Female labor supply: Theory and estimation. Princeton, N.J.: Princeton University Press.

Shikata, M., \& Ma, X. (2006). Does the balance support policy in the 1990s promote the labor supply of married women? In Y. Higuchi, et al. (Eds.), The dynamics of household behavior in Japan: Tax system reform and household response (pp. 169-190). Tokyo: Keio University Press. (In Japanese).

Smith, J. P. (1980). Assets and labor supply. In J. P. Smith (Ed.), Female labor supply: Theory and estimation. Princeton, N.J.: Princeton University Press. 
Waite, L. J., Haggstrom, G. W., \& Kanouse, D. E. (1985). Changes in the employment activities of new parents. American Sociological Review, 50(2), 263-272.

Wang, F., Cai, Y., \& Gu, B. (2013). Population, policy, and politics: How will history judge China's one-child policy? Population \& Development Revie, 38(s1), 115-129.

Wenk, D., \& Garrett, P. (1992). Having a baby: Some predictions of maternal employment around childbirth. Gender \& Society, 6(1), 49-65.

Wu, Y. (2009). The destination of informal employment. Economic Research Journal, 7, 91-106. (In Chinese).

Yang, H., \& Bai, L. (2017). Canonical correlation analysis of second child birth and women's employment in urban China. Journal of China Women's University, 3, 5-13. (In Chinese).

Yu, J., \& Xie, Y. (2014). The effect of fertility on women's wage in China. Population Research, 1, 18-29. (In Chinese).

Zabalza, A. (1983). The CES utility function, non-linear budget constraints and labour supply: Results on female participation and hours. Economic Journal, 93(7), 312-330.

Zhang, C. (2011). Impacts of number of children on the labor supply and wage earnings of married women. Population \& Economics, 5, 29-35. (In Chinese).

Zhang, K., Liu, C., \& Ding, S. (2018). Research on the wage differences between formal employment and informal employment. Chinese Journal of Population Science, 1, 83-194. (In Chinese).

Zhang, X., \& Hu, L. (2017). Informal employment of Chinese women: Based on the economics on human development. Reformation \& Strategy, 2, 1-4. (In Chinese).

Zhang, Y., \&. Qin, B. (2015). Research on the wage gap between urban informal labor and formal labor. Population Journal, 4, 92-103. (In Chinese).

Open Access This chapter is licensed under the terms of the Creative Commons AttributionNonCommercial-NoDerivatives 4.0 International License (http://creativecommons.org/licenses/bync-nd/4.0/), which permits any noncommercial use, sharing, distribution and reproduction in any medium or format, as long as you give appropriate credit to the original author(s) and the source, provide a link to the Creative Commons licence and indicate if you modified the licensed material. You do not have permission under this licence to share adapted material derived from this chapter or parts of it.

The images or other third party material in this chapter are included in the chapter's Creative Commons licence, unless indicated otherwise in a credit line to the material. If material is not included in the chapter's Creative Commons licence and your intended use is not permitted by statutory regulation or exceeds the permitted use, you will need to obtain permission directly from the copyright holder.

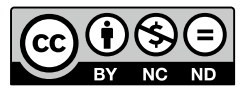

